\title{
PENGARUH PENGGUNAAN MULTIMEDIA TERHADAP HASIL BELAJAR SISWA SMK PADA STANDAR KOMPETENSI MERAWAT BATERAI
}

\author{
Trio Wahyudin ${ }^{1}$, Dedi Supriawan ${ }^{2}$, Mumu Komaro $^{3}$ \\ Departemen Pendidikan Teknik Mesin \\ Universitas Pendidikan Indonesia \\ Jl. Dr. Setiabudhi No. 207 Bandung 40154 \\ triownsanury@yahoo.com
}

\begin{abstract}
ABSTRAK
Penelitian ini bertujuan untuk mengetahui hasil belajar siswa yang menggunakan media pembelajaran multimedia lebih baik dari pada penggunaan media pembelajaran klasikal pada standar kompetensi Memelihara Baterai di SMK Negri 6 Bandung. Metode penelitian yang digunakan adalah metode kuasi eksperimen dengan desain penelitian menggunakan Pretest-Posttest Nonequivalent Control Group Design. Populasi penelitian ini adalah seluruh siswa kelas X TKR SMK Negri 6 Bandung. Sampel yang diambil dalam penelitian ini hanya dua kelas yaitu kelas X TKR 2 sejumlah 33 siswa sebagai kelas eksperimen dan kelas X TKR 4 sejumlah 33 siswa sebagai kelas kontrol. Hasil analisis data mendapatkan bahwa hasil belajar siswa yang menggunakan media pembelajaran multimedia lebih baik dari pada media klasikal, Hal ini bisa dilihat dari nilai rata-rata hasil akhir (Posttest). Nilai rata-rata pada kelas yang menggunakan multimedia (kelas eksperimen) sebesar 82,42 sedangkan kelas yang menggunakan pembelajaran klasikal (kelas kontrol) sebesar 74,91 dengan skala penilaian 0-100.
\end{abstract}

Kata kunci: multimedia, merawat, baterai, hasil belajar.

\section{PENDAHULUAN}

Pendidikan sebagai proses pembentukan pribadi. Sebagai proses pembentukan pribadi, pendidikan diartikan sebagai suatu kegiatan yang sistematis, sistemik dan terarah pada terbentuknya kepribadian peserta didik. Sesuai UU No. 20 Tahun 2003, tentang sistem pendidikan nasional, pendidikan adalah usaha sadar dan terencana untuk mewujudkan suasana belajar dan proses pembelajaran agar peserta didik secara aktif mengembangkan potensi dirinya untuk memiliki kekuatan spiritual keagamaan, pengendalian diri, kepribadian, kecerdasan, akhlak mulia, serta ketrampilan yang diperlukan dirinya, masyarakat, bangsa dan Negara. Pendidikan di Indonesia terbagi menjadi tiga jalur utama, yaitu pendidikan formal, pendidikan nonformal, dan pendidikan informal. Sekolah Menengah Kejuruan merupakan salah satu pendidikan formal yang diselenggarakan oleh pemerintah yang berbasis keterampilan dibidang produktif, yang mengarahkan peserta didik untuk menjadi lulusan siap kerja dan menjadi tenaga kerja yang berkualitas serta mampu bersaing di era globalisasi (Mulyasa, 2004).

\footnotetext{
${ }^{1}$ Mahasiswa Departemen Pendidikan Teknik Mesin FPTK UPI

${ }^{2}$ Dosen Departemen Pendidikan Teknik Mesin FPTK UPI

${ }^{3}$ Dosen Departemen Pendidikan Teknik Mesin FPTK UPI
} 
Keberadaan Sekolah Menengah Kejuruan perlu didukung adanya sarana dan prasarana sebagai penunjang berlangsungnya proses kegiatan belajar mengajar. Sesuai PP No. 19 Tahun 2005, tentang Standar Nasional Pendidikan, pada BAB VII (Sarana dan Prasarana), Pasal 42, Butir 1: Setiap satuan pendidikan wajib memiliki sarana yang meliputi perabot, peralatan pendidikan, media, pendidikan, buku dan sumber belajar lainnnya, bahan habis pakai, serta perlengkapan yang teratur dan berkelanjutan. Peraturan ini menunjukkan media pendidikan merupakan salah satu sarana yang dipergunakan untuk menunjang proses pembelajaran. Penggunaan media dalam proses belajar mengajar diharapkan mampu menumbuhkan minat dan motivasi belajar, memperjelas fakta, dan diharapkan pula siswa lebih mudah memahami dan mengerti materi yang disampaikan guru (Hamalik, 2003). Saat ini media yang digunakan di SMKN 6 Bandung dalam mendukung proses pembelajaran di kelas, antara lain: papan tulis, proyektor, dan power point yang masih didominasi tulisan dan gambar diam. Beberapa media tersebut masih cenderung menggunakan mata sebagai indra dominan untuk menangkap pesan, sehingga indra pendengar belum sepenuhnya digunakan. Kemampuan siswa dalam menangkap materi pembelajaran salah satunya ditentukan oleh keoptimalan mereka dalam menggunakan panca indra. Mata dan telinga merupakan bagian indra yang paling berperan dalam menangkap seluruh informasi pembelajaran.

Situasi yang diamati dan dialami penulis berdasarkan hasil observasi awal dan saat melaksanakan Program Pengalaman Lapangan di SMKN 6 Bandung, pada saat berlangsungnya kegiatan proses belajar mengajar di kelas teori khususnya pada Standar Kompetensi Memelihara Baterai menunjukkan ketertarikan siswa dalam mengikuti proses belajar mengajar belum terpenuhi sampai tuntas (Abdorrakhman, 2010). Hal ini dapat dilihat beberapa siswa izin ke luar kelas lebih dari 15 menit bahkan mereka tidak kembali ke kelas. Keaktifan siswa dalam mengikuti proses pembelajaran Standar Kompetensi Memelihara Baterai masih rendah, hal ini dapat ditunjukkan belum ada keberanian siswa untuk menjawab pertanyaan yang diberikan oleh guru. Perhatian siswa dalam mengikuti proses pembelajaran Standar Kompetensi Memelihara Baterai masih rendah, hal ini dapat dilihat beberapa siswa terlihat tidak konsentrasi selama mengikuti pelajaran, seperti: ada yang mengantuk, berpindah-pindah tempat, kurang memperhatikan materi yang disampaikan guru, masih mengganggap kegiatan belajar kurang menyenangkan dan memilih kegiatan lain diluar konteks belajar seperti sms atau bercanda dengan teman sebaya. Proses kegiatan belajar-mengajar masih sederhana yang hanya mendominasi kegiatan belajar seperi: mencatat di papan tulis, dikte, ceramah, modul atau buku paket, 
kemudian pemberian tugas. Media Pembelajaran yang digunakan masih belum bisa mendukung proses belajar mengajar yang menyenangkan dan bervariatif, misalnya saat guru menggunakan media pembelajaran dengan modul belum memaksimalkan fitur-fitur yang ada seperti video ataupun animasi.

Permasalahan pembelajaran di kelas juga berpengaruh terhadap hasil belajar siswa. Keterbatasan pembelajaran di kelas khususnya pada pembelajaran Standar Kompetensi Memelihara Baterai yang membahas tentang Kompetensi Dasar Merawat Baterai secara teori cukup sulit dipahami, keterbatasan ini perlu didukung dengan adanya saran media pembelajaran (Nasution, 2003). Pemilihan media pembelajaran harus benar-benar tepat dan dapat mempermudah dalam penyampaian materi, agar semua pesan yang ingin disampaikan guru dapat diterima secara keseluruhan oleh siswa. Media pembelajaran merupakan suatu sarana komunikasi pembawa pesan dari sumber pesan kepada penerima pesan untuk menunjang proses pembelajaran. Media pembelajaran membuat pengajaran akan lebih menarik perhatian siswa, materi pelajaran akan lebih jelas maknanya, sehingga akan lebih mudah dipahami oleh siswa (Susilana dan Riyana, 2008). Media pembelajaran juga membuat metode mendidik akan lebih bervariasi, tidak semata-mata komunikasi verbal melalui penuturan kata-kata oleh guru, sehingga siswa tidak bosan dan guru tidak kehabisan tenaga.

Diperlukan strategi untuk meningkatkan hasil belajar siswa berupa pemanfaatan multimedia. Melalui multimedia ini diharapkan indra penglihatan dan pendengaran berperan sepenuhnya dalam menangkap seluruh informasi pembelajaran, serta dapat meningkatkan hasil belajar siswa supaya konsentrasi dalam proses pembelajaran lebih terfokus dan berusaha untuk meraih prestasi semaksimal mungkin. Multimedia adalah suatu media yang terdiri dari media visual yang disinkronkan dengan media audio, yang sangat memungkinkan terjalinnya komunikasi dua arah antara guru dan anak didik di dalam proses belajar-mengajar (Sagala, 2005).

\section{METODE PENELITIAN}

Metode yang digunakan dalam penelitian ini adalah metode kuasi eksperimen (Quasi Exsperimental Design). Selama melakukan eksperimen, siswa merupakan objek penelitian yang tetap mengikuti pelajaran dalam kelas seperti biasa. Desain penelitian yang digunakan dalam penelitian ini adalah (Nonequivalent Control Group Design) yaitu menempatkan subjek penelitian ke dalam dua kelompok kelas yang terdiri dari kelompok eksperimen dan kelompok kontrol yang tidak dipilih secara acak. 


\section{HASIL PENELITIAN}

Hasil belajar dilihat dari hasil perolehan tes sub sumatif siswa dengan skala nilai 0100, setelah dilakukan tes awal (pre test) dan tes akhir (post test). Data yang diperoleh dari hasil pre test dan post test akan memberikan gambaran kemampuan siswa terhadap standar kompetensi dasar memelihara/servis baterai. Data pre test dan post test tersebut maka akan diperoleh data kemampuan siswa. Data pre test memberikan gambaran kemampuan awal siswa sebelum memperoleh materi pembelajaran. Deskripsi data hasil pre test kelas kontrol dan kelas eksperimen. Data post test memberikan gambaran kemampuan akhir siswa setelah memperoleh materi pembelajaran (perlakuan). Data post test ini (Tabel 1) diperoleh dari tes tertulis (pilihan ganda) dengan jenis tes dan jumlah soal sama seperti pada pre test.

Tabel 1. Data pre test dan post test berdasarkan kelas

\begin{tabular}{lcccc}
\hline \multirow{2}{*}{ Data } & \multicolumn{2}{c}{ Pre test } & \multicolumn{2}{c}{ Post test } \\
\cline { 2 - 5 } & Kontrol & Eksperimen & Kontrol & Eksperimen \\
\hline Jumlah sampel & 33 & 33 & 33 & 33 \\
Skor minimum & 40 & 36 & 60 & 64 \\
Skor maksimum & 80 & 68 & 88 & 100 \\
Rentang (R) & 40 & 32 & 28 & 36 \\
Rata-rata $(x)$ & 60,36 & 47,88 & 74,91 & 82,42 \\
Standar deviasi (s) & 8,69 & 7,59 & 8,08 & 8,79 \\
\hline
\end{tabular}

Catatan: Skala 0-100

Uji normalitas dan homogenitas yang telah dilakukan sebelumnya didapatkan kesimpulan bahwa data post test dari kedua sampel yaitu kelas kontrol dan kelas eksperimen berdistribusi normal dan berasal dari populasi dengan varians yang sama. Tahap berikutnya, yaitu dengan melakukan uji kesamaan dua rata-rata hasil untuk melihat apakah kedua sampel memiliki rata-rata post test yang sama dengan menguji signifikan perbedaan rata-rata. Hasil uji kesamaan rata-rata menggambarkan bahwa data nilai post test dari kelas eksperimen dan kelas kontrol didapat nilai $t_{\text {hitung }}$ sebesar 3,47 . Nilai $t_{\text {tabel }}$ pada $\mathrm{dk}=64$ pada derajat kepercayaan 95\% diperoleh sebesar 1,67. Hal ini menunjukan bahwa $t_{\text {hitung }}>t_{\text {tabel }}$ sehingga dapat disimpulkan bahwa hasil belajar kelas eksperimen lebih baik dibandingkan dengan kelas kontrol setelah diberikan perlakuan, atau $\mathrm{H}_{0}$ ditolak dan diterima $\mathrm{H}_{\mathrm{a}}$.

\section{PEMBAHASAN}

Media pembelajaran merupakan suatu sarana komunikasi pembawa pesan dari sumber pesan kepada penerima pesan untuk menunjang proses pembelajaran. Media 
pembelajaran membuat pengajaran akan lebih menarik perhatian siswa, materi pelajaran akan lebih jelas maknanya, sehingga akan lebih mudah dipahami oleh siswa. Media pembelajaran juga membuat metode mendidik akan lebih bervariasi, tidak semata-mata komunikasi verbal melalui penuturan kata-kata oleh guru, sehingga siswa tidak bosan dan guru tidak kehabisan tenaga (Slameto, 2003).

Keunggulan multimedia antara lain: (1) mampu menampilkan objek-objek yang sebenarnya tidak ada secara fisik atau diistilahkan dengan imagery. Secara kognitif pembelajaran dengan menggunakan mental imagery akan meningkatkan retensi siswa dalam mengingat materi-materi pelajaran, (2) mampu mengembangkan materi pembelajaran terutama membaca dan mendengarkan secara mudah, (3) memiliki kemampuan dalam menggabungkan semua unsur media seperti teks, gambar, video, grafik, tabel, suara dan animasi menjadi satu kesatuan penyajian yang terintegrasi, (4) dapat mengakomodasi peserta didik sesuai dengan modalitas belajarnya terutama bagi mereka yang memiliki tipe visual, auditif, kiestetik, atau yang lainnya (Munadi, 2013).

Diperlukan strategi untuk meningkatkan hasil belajar siswa berupa pemanfaatan multimedia. Melalui multimedia ini diharapkan indra penglihatan dan pendengaran berperan sepenuhnya dalam menangkap seluruh informasi pembelajaran, serta dapat meningkatkan hasil belajar siswa supaya konsentrasi dalam proses pembelajaran lebih terfokus dan berusaha untuk meraih prestasi semaksimal mungkin. Multimedia adalah suatu media yang terdiri dari media visual yang disinkronkan dengan media audio, yang sangat memungkinkan terjalinnya komunikasi dua arah antara guru dan anak didik di dalam proses belajar-mengajar.

Sebelum proses pembelajaran atau tes awal (pre test), menunjukan bahwa kemampuan awal kelas eksperimen yaitu nilai rata-rata kelas kelas eksperimen 47,88. Perbedaan hasil belajar pada ranah kognitif ini disebabkan beberapa faktor, seperti faktor motivasi siswa dan faktor belum menguasai materi pembelajaran (Susilo, 2007). Setelah proses pembelajaran dilaksanakan atau tes akhir (post test) dengan media pembelajaran menggunakan multimedia untuk kelas eksperimen, hasil rata-rata nilai kelas eksperimen 82,42 .

Umumnya pelaksanaan pembelajaran mencakup tiga hal: sebelum pembelajaran, proses, dan setelah pembelajaran (Mulyasa, 2004). Melalui ketiga langkah tersebut diperoleh data hasil penelitian, hasil belajar siswa dapat diperoleh dari proses belajar mengajar yang diukur melalui tes. Kegiatan tes dilakukan dua kali yaitu tes sebelum proses pembelajaran dan setelah peroses pembelajaran. Sebelum proses pembelajaran atau tes 
awal (pre test), menunjukan bahwa kemampuan awal siswa kelas kontrol yaitu nilai ratarata kelas kontrol 60,36. Setelah proses pembelajaran dilaksanakan atau tes akhir (post test) dengan media pembelajaran klasikal untuk kelas kontrol, hasil rata-rata yaitu 74,91.

Perbedaan hasil belajar setelah dilakukan proses pembelajaran dikarenakan penggunanan media pembelajaran. Manfaat penggunaan media dalam belajar dan pembelajaran: penyampaian materi dapat diseragamkan, proses intruksional lebih menarik, proses belajar lebih intraktif, jumlah waktu belajar-mengajar dapat dikurangi, kualitas belajar dapat ditingkatkan, proses belajar dapat terjadi kapan dan di mana saja, peningkatkan sikap positif siswa terhadap proses dan bahan belajar, dan peran pengajar dapat berubah kearah positif dan produktif (Abdorrakhman, 2010).

Nilai rata-rata pre test kedua kelas, yaitu nilai rata-rata kelas kontrol 60,36 sedangkan kelas eksperimen 47,88. Setelah diberi perlakuan menggunakan multimedia lalu dilakukan post test hasil rata-rata nilai kedua kelas yang memperoleh selisih nilai yang cukup tinggi yaitu 74,91 pada kelas kontrol dan 82,42 pada kelas eksperimen, dengan demikian multimedia memberikan pengaruh yang cukup besar terhadap hasil belajar siswa (Sudjana, 2001).

\section{KESIMPULAN}

Penelitian ini dapat disimpulkan, yaitu hasil belajar siswa pada standar kompetensi memelihara baterai menggunakan multimedia berdasarkan rata-rata pre-test 47,88 dan post-test 82,42 terjadi perubahan yang lebih baik dilihat dari nilai rata-rata. Hasil belajar siswa pada standar kompetensi memelihara baterai menggunakan pembelajaran klasikal berdasarkan rata-rata pre-test 60,36 dan post-test 74,91. Perbedaan hasil belajar siswa pada standar kompetensi memelihara baterai menggunakan multimedia lebih baik dilihat dari nilai post-test dibandingkan dengan menggunakan pembelajaran klasikal.

\section{DAFTAR PUSTAKA}

Abdorrakhman, G. (2010). Esensi Praktis Belajar dan Pembelajaran. Bandung: Humaniora.

Hamalik, O. (2003). Proses Belajar. Bandung: Sinar Baru Algesindo.

Mulyasa, E. (2004). Implementasi Kurikulum Panduan Pembelajaran. Bandung: PT. Remaja Rosdakarya.

Munandi, Y. (2013). Media Pembelajaran: Manual dan Digital. Bogor: Ghahila Indonesia. 
Nasution, S. (2003). Berbagai Pendekatan dalam Proses Belajar dan Mengajar. Jakarta: Bumi Aksara.

Sagala, S. (2005). Konsep dan Makna Pembelajaran. Bandung: Alfabeta

Sudjana, N. (2001). Penilaian Hasil Proses Belajar Mengajar. Bandung: Remaja Rosdakarya.

Susilana dan Riyana. (2008). Media Pembelajaran. Bandung: Jurusan Kurtekpend FIP UPI.

Susilo, M. J. (2007). Kurikulum Tingkat Satuan Pendidikan Manajemen Pelaksanaan dan Kesiapan Sekolah Menyonsongnya. Pustaka Pelajar. Yogyakarta.

Slameto. (2003). Belajar dan Faktor-Faktor Yang Mempengaruhinya. Jakarta: Rosdakarya. 